\title{
Vaginal Rhabdomyoma
}

National Cancer Institute

\section{Source}

National Cancer Institute. Vaginal Rhabdomyoma. NCI Thesaurus. Code C6372.

A rare benign polypoid skeletal muscle neoplasm arising from the vagina. It is characterized by the presence of round striated muscle cells and strap-like skeletal muscle cells, and vascular space formations within a fibrous and myxoid stroma. 